\title{
PREDIKSI RISIKO PASAR DAN KEUNTUNGAN DENGAN MODEL CAPM SEBAGAI DASAR PENGAMBILAN KEPUTUSAN BERINVESTASI PADA SAHAM JAKARTA ISLAMIC INDEX PERIODE TAHUN 2006 - 2008
}

\author{
Oleh: \\ Devi Ika Waryani \\ Staff KSU Mulyo Agung Malang \\ E-mail/No. Hp: - /085649997507
}

\begin{abstract}
There are three purposes in this research are to know stock beta belong to JII, to know beta as risk premi (Rm-Rf) intended by third market, to know the result CAPM model count as basic investment decision making Securitas on JII stock. The method used from this research is descriptive of kualitative it means the purpose of this research to describe situation from count result. From the result above show that CAPM model can prove beta as risk level positive improve and significance although less more 1 value, it means fluctuation stock more weak and lower concerning index market fluctuation. The result grouping criteria was got decision suggestion inclining aim to buy stock because on the prediction to buy that stock in cheap so chance to investor increase their stock.
\end{abstract}

Keywords: risk, return, CAPM model

\section{PENDAHULUAN}

Pasar modal merupakan wahana yang di manfaatkan untuk memobilitsasi dana masyarakat. Keberadaannya bukan hanya sebagai sumber pembiayaan saja tetapi juga sebagai sarana investasi yang melibatkan seluruh potensi dana masyarakat, baik masyarakat dalam negeri maupun luar negeri. Pengertian pasar modal menurut Undang-undang Nomor 8 Tahun 1995 adalah Bursa efek merupakan pihak yang menyelenggarakan dan menyediakan sistem atau sarana untuk mempertemukan penawaran jual dan beli efek pihak-pihak lain dengan tujuan memperdagangkan efek diantara mereka. Yang mana dapat dimanfaatkan bagi investor untuk menginvestasikan dananya sehingga menambah pilihan investasi. Akibat dari banyaknya pilihan investasi yang ditawarkan, tentunya investor perlu beberapa pertimbanganpertimbangan seperti informasi keuangan, perhitungan dan analisis yang memadai serta perlu mengetahui keadaan dan prospek perusahaan yang menjual sahamnya di pasar modal.

Dalam memutuskan untuk berinvestasi atas saham-saham harus lebih selektif dalam memilih sahamsaham yang menguntungkan. Investor terlebih dahulu harus biasa memperkirakan risiko-risiko yang akan dihadapi serta keuntungan yang akan diperoleh atau memperkirakan keuntungan yang diharapkan (expected return) lebih besar dari keuntungan yang diperoleh (realize return) tidak baik untuk dibeli. Karena hal itu menunjukkan bahwa hal tersebut tidak dapat memenuhi harapan dari para 
investor. Dengan demikian maka saham yang baik untuk dibeli adalah saham dengan keuntungan yang diperoleh lebih besar dari keuntungan yang diharapkan. Yang intinya modal dana dan pengetahuan belumlah cukup untuk membuat investasi dapat berhasil sesuai dengan yang diharapkan. Satu hal lain yang diperlukan adalah ketepatan dalam pemilihan berbagai instrument investasi yang ada.

Ada dua tujuan seorang investor dalam menanamkan modalnya . Pertama, seorang investor bertujuan mencapai capital gain, yaitu selisih antara harga jual dengan harga beli. Investor seperti ini cenderung melihat pada perubahan harga jual dengan harga beli. Kedua adalah investor yang melihat pada besarnya deviden. Hal ini dapat diperoleh dengan mempelajari, menganalisa dan menilai informasi yang didapat. Informasi tersebut antara lain : prospectus (gambaran umum perusahaan), laporan keuangan, besarnya perusahaan, nilai kapitalisasi saham, jumlah emisi yang merupakan syarat pokok bagi perusahaan yang akan Go publik.

Permasalahan klasik yang timbul dalam aktivitas investasi adalah kombinasi antara resiko dengan tingkat pengembalian investasi (return) yang bagaimana yang harus dipilih, serta masalah, jenis dan periode waktu investasi, serta apakah peragaman (diversifikasi) pada investasi saham dapat mengurangi risiko investasi pada portofolio saham.

Menurut Halim (2003:50) portofolio merupakan kombinasi atau gabungan atau sekumpulan asset, baik berupa real asset maupun financial asset yang dimiliki oleh investor. Hakikat pembentukan portofolio adalah untuk mengurangi risiko dengan cara diversifikasi, yaitu mengalokasikan sejumlah dana pada berbagai alternative investasi yang berkorelasi negative.

Banyak strategi dan metode yang dapat digunakan dalam menganalisis dan mengevaluasi saham-saham yang ditawarkan di pasar modal, tetapi yang paling mendasar dalam analisis tersebut adalah dengan memperhitungkan faktor risiko atau ketidakpastian dan menentukan tingkat keuntungan yang diharapkan dengan mengestimasi return suatu sekuritas individu. Investor yang mengharapkan memperoleh keuntungan yang lebih besar maka ia harus bersedia menanggung risiko yang lebih besar sebaliknya yang tidak bersedia menanggung risiko tinggi, maka keuntungan yang diharapkan rendah.

Investasi yang efisien adalah investasi yang memberikan risiko tertentu dengan tingkat keuntungan yang terbesar atau tingkat keuntungan tertentu dengan tingkat risiko kecil. Dengan kata lain jika ada usulan investasi yang memberikan tingkat keuntungan yang sama tetapi risiko yang berbeda, maka investor yang rasional akan memilih investasi yang mempunyai risiko kecil.

Untuk itu diperlukan suatu teori yang dapat dipergunakan untuk mengestimasi return suatu sekuritas, sehingga dapat ditentukan berapa tingkat keuntungan dan risiko pada saham. Capital Asset Princing Model (CAPM) merupakan suatu teori yang menjelaskan hubungan antara risiko dan tingkat keuntungan.

Berdasarkan uraian latar belakang maka dapat diambil rumusan masalah 1) Seberapa besar risiko beta $(\beta)$ pada saham-saham yang tergolong JII? 2)Apakah beta pasar menunjukan premi risiko yang dikehendaki pasar? 3)Bagaimana hasil perhitungan model CAPM sebagai dasar pengambilan keputusan investasi sekuritas saham JII? 


\section{TINJAUAN PUSTAKA}

Apabila setiap pemodal individual bertindak seperti yang diperkirakan, maka akan berhasil merumuskan bagaimana seluruh pemodal akan berperilaku, dan karenanya bagaimana harga dan tingkat keuntungan akan ditentukan oleh pasar. Pembentukan model-model umum memungkinkan untuk menentukan pengukur risiko yang relevan dan bagaimana hubungan antara risiko untuk setiap asset apabila pasar modal berada dalam keadaan seimbang, salah satu model keseimbangan tersebut yaitu Capital Asset Pricing Model. CAPM bertujuan untuk menentukan minimum required return dari investasi yang berisiko.

Menurut Jogiyanto (2000:312) Dalam hal standard CAPM, asumsiasumsi yang dipergunakan yaitu: Pertama, Semua investor mempunyai cakrawala waktu satu periode yang sama. Investor memaksimumkan kekayaannya dengan memaksimumkan utility harapan dalam satu periode waktu yang sama.

Kedua, Semua investor melakukan pengambilan keputusan investasi berdasarkan pertimbangan antara nilai return ekspektasi dan deviasi standar return dari portofolionya.

Ketiga, Semua investor mempunyai harapan yang seragam (homogeneous expectation) terhadap faktor-faktor input yang digunakan untuk kepuasan investor. Faktor-faktor input yang digunakan adalah return ekspektasi (expected return), varian dari return dan kovarian antara return-return sekuritas. Asumsi ini mempunyai implikasi bahwa dengan harga-harga sekuritas dan tingkat bunga bebas risiko yang tertentu dan dengan mengunakan input-input portofolio yang sama, maka setiap investor akan menghasilkan efficient frontier yang sama pula.
Keempat, Semua investor dapat meminjamkan sejumlah dananya (lending) atau meminjam (borrowing) sejumlah dana dengan jumlah yang tidak terbatas pada tingkat suku bunga bebas risiko. Kelima, Penjualan pendek (short sale) diijinkan. Investor individual dapat menjual pendek berapapun yang dikehendaki.

Keenam, Semua aktiva dapat dipecah-pecah menjadi bagian yang lebih kecil dengan tidak terbatas. Ini berarti bahwa dengan nilai yang terkecilpun investor dapat melakukan investasi dan melakukan traksaksi penjualan dan pembelian aktiva setiap saat dengan harga yang berlaku. Ketujuh, Tidak ada biaya transaksi. Penjualan atau pembelian aktiva tidak dikenai biaya transaksi. Kedelapan, Tidak terjadi inflasi.

Kesembilan, Tidak ada pajak pendapatan pribadi. Karena tidak ada pajak pribadi, maka investor mempunyai pilihan yang sama untuk mendapatkan deviden atau capital gain. Kesepuluh, Investor adalah penerima harga (price takers). Investor individual tidak dapat mempengaruhi harga dari suatu aktiva dengan kegiatan membeli dan menjual aktiva tersebut. Investor secara keseluruhan bukan secara individual menentukan harga dari aktiva. Kesebelas, Pasar modal dalam keadaan ekuilibrium.

Menurut Husnan (1993:103) apabila investor memasukkan kesempatan investasi yang bebas risiko, maka beta investasi ini $=0$, dan tingkat keuntungannya $=\mathrm{Rf}$, sedangkan beta portofolio pasar $=1$. Hal ini terjadi karena covariance portofolio pasar dengan portofolio pasar tidak lain sama dengan $\sigma_{M}{ }^{2}$. Karena itu $\beta M=\sigma_{M}^{2} / \sigma_{M}^{2}=$ 1. Sedangkan tingkat keuntungan yang diharapkan dari portofolio pasar $=$ $\mathrm{E}(\mathrm{RM})$. 
Apabila keadaan ini digambarkan dalam diagram yang sumbu datarnya $B$ dan sumbu tegaknya $\mathrm{E}(\mathrm{R})$, dan akan memperoleh gambar sebagai berikut.

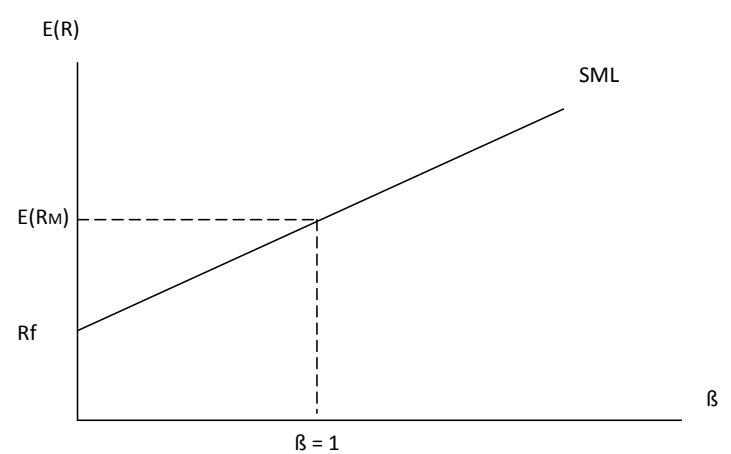

Gambar 1. Security Market Line Sumber : Husnan. 1993.

Pada gambar diatas bahwa security market line tersebut tidak lain merupakan persamaan garis regresi dengan intercept $=\mathrm{Rf}$ dan slope $=$ $\mathrm{E}(\mathrm{RM})$ - Rf. Dengan demikian maka untuk sekuritas i tingkat keuntungan yang diharapakan bisa dinyatakan sebagai.

$$
\mathbf{E}(\mathbf{R i})=\mathbf{R f}+\boldsymbol{B i}[\mathbf{E}(\mathbf{R M})-\mathbf{R f}]
$$

Formula inilah yang dirumuskan oleh tiga orang, yaitu Jack Treynor, William sharpe dan John Lintner, pada pertengahan tahun 1960-an dan dikenal sebagai Capital Asset Pricing Model (CAPM).

Pada gambar dibawah ini menunjukan adanya keadaan ekuilibrium dengan garis RfMZ sebagai garis pasar modal (Capital Market Line). Titik M menunjukan portofolio pasar. Slope garis pasar modal (yaitu RfMZ) adalah

$$
\left(\mathbf{R}_{\mathbf{M}}-\mathbf{R f}\right) / \boldsymbol{\sigma}_{\mathbf{M}}
$$

Sedangkan pada gambar tersebut titik i menunjukan suatu surat berharga yang berisiko (dan tidak efisien). Dengan demikian kalau bisa menemukan suatu hubungan antara tingkat keuntungan dengan risiko untuk saham i, bisa mengunakan formula ini untuk semua saham lainnya.

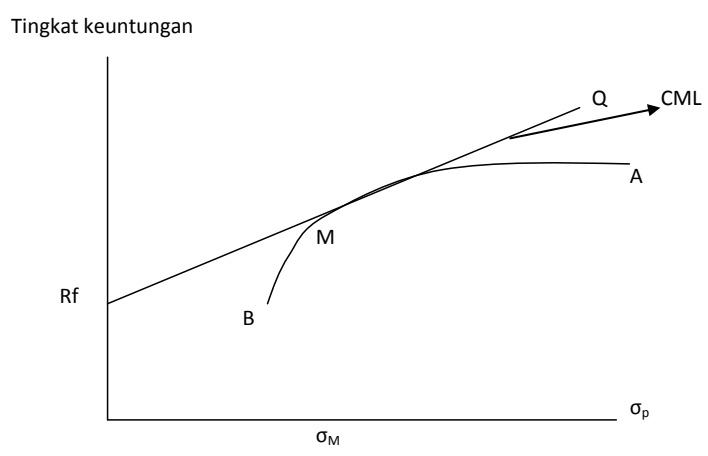

Gambar 2. Capital Market Line (CML) atau Garis Pasar Modal (GML)

Sumber : Husnan. 1993.

Keadaan ekuilibrium pasar yang menyangkut return ekspektasi dan risiko dapat digambarkan oleh garis pasar modal (GPM) atau capital market line (CML). Garis lurus Rf - Q di gambar 8 adalah garis pasar modal (GPM). Jika garis ini digambarkan kembali dengan mengunakan efficient set, maka akan tampak di gambar 8 seperti di atas.

Kurva efficient set terletak pada garis $\mathrm{AB}$ dan dalam keadaan ekuilibrium semua aktiva berisiko harus berada di portofolio pasar (M) karena semua investor akan memagang portofolio ini. Garis pasar modal menunjukan semua kemungkinan kombinasi portofolio efisien yang terdiri dari aktiva-aktiva berisiko dan aktiva bebas risiko. Jika portofolio pasar hanya berisi aktiva tidak berisiko, maka risikonya akan sama dengan nol $\left(\sigma_{\mathrm{p}}=0\right)$ dan return ekspektasinya sama dengan Rf. Jika portofolio ini terdiri dari semua aktiva yang ada, maka risikonya adalah sebesar $\sigma_{\mathrm{p}}$ dengan return ekspektasinya sebesar $\mathrm{E}\left(\mathrm{R}_{\mathrm{M}}\right)$. return ekspektasi untuk portofolio aktiva berisikjo yaitu $\mathrm{E}\left(\mathrm{R}_{\mathrm{M}}\right)$, lebih besar dibandingkan dengan return 
return ekspektasi portofolio dengan aktriva yang tidak berisiko (Rf). Selisih kedua return ini sebesar $\left[E\left(R_{M}\right)-R f\right]$ merupakan premium dari portofolio pasar karena menanggung risiko lebih besar yaitu sebesar $\sigma_{M}$. Maka rumus yang dapat ditulis adalah dimana sering disebut sebagai standar CAPM.

$$
\mathbf{E}(\mathbf{R i})=\mathbf{R f}+\left[\mathbf{E}\left(\mathbf{R}_{\mathbf{M}}\right)-\mathbf{R f}\right] \mathbf{B i}
$$

Notasi:

$\mathrm{E}(\mathrm{Ri})=$ return ekspektasi per saham $\mathrm{i}$; $\mathrm{Rf}=$ aktiva bebas risiko; $\mathrm{E}(\mathrm{Rm})=$ return portofolio pasar; $\beta \mathrm{i}=$ beta per saham $\mathrm{i}$.

\section{METODE PENELITIAN}

Menurut Jogiyanto (2000:60) Indeks Harga Saham Jakarta Islamic Index adalah indeks yang mencerminkan perkembangan harga saham pada perusahaan yang tergolong saham JII.

Nilai Pasar

$$
\text { IHJI }_{\mathbf{t}}=\frac{}{\text { Nilai Dasar }} \times \mathbf{1 0 0}
$$

Notasi :

IHJI = indeks harga saham

Jakarta Islamic Index hari ke t

Nilai Pasar $=$ rata-rata tertimbang nilai pasar (jumlah lembar saham dikalikan dengan harga pasar perlembarnya) dan saham umum dan saham preferen pada hari ke t; Nilai Dasar= sama dengan nilai pasar tetapi nilai dimulai pada hari itu juga.

Menurut Jogiyanto (2000:108) Capital gain (loss) merupakan selisih dari harga investasi sekarang relatif dengan harga periode yang lalu:

$$
\mathrm{Ri}=\frac{\mathrm{Pt}-\mathrm{Pt}_{(-1)}}{\mathrm{Pt}_{(-1)}}
$$

Notasi :

$\mathrm{Ri}=$ return yang sesungguhnya diterima investor individual; $\mathrm{Pt}=$ harga saham periode $\mathrm{t} ; \mathrm{Pt}_{(-1)}=$ harga saham pada periode sebelum periode $t$.
Menurut Jogiyanto (2000:204) Return pasar adalah tingkat keuntungan bulanan seluruh saham yang dihitung dari rasio selisih Indeks Harga Saham Jakarta Islamic Index (IHJI).

Pengukuran Return Pasar:

$$
\mathrm{Rm}=\frac{\mathrm{IHJI}_{\mathrm{t}}-\mathrm{IHJI}_{\mathrm{t}-1}}{\mathrm{IHJ} \mathrm{t}_{\mathrm{t}-1}}
$$

Notasi :

$\mathrm{Rm}=$ Return portofolio pasar; IHJIt= Indeks harga saham Jakarta Islamic Index pada periode $\mathrm{t} ;$ IHJIt $_{(-1)}=$ Indeks harga saham Jakarta Islamic Index pada periode sebelum periode $t$.

Menurut Jogiyanto (2000:194) Tingkat pengembalian bebas risiko, biasanya diukur dari suku bunga SBI 1 bulan. SBI merupakan instrument moneter yang diterbitkan oleh BI terutama yang mengendalikan jumlah peredaran uang yang ada. SBI tidak dipengaruhi oleh harga sekuritas yang lain dan tidak diperjulabelikan di bursa saham. Sehingga untuk mencari nilai tingkat pengembalian bebas risiko adalah:

$\mathrm{Rf}=\frac{\text { Tingkat bunga SBI perbulan }}{}$ n

Notasi: $\mathrm{Rf}=$ tingkat pengembalian bebas risiko; $\mathrm{n}=12$ bulan per suku bunga SBI

Menurut Jurnal Systematic Risk In Emerging Markets: The D-CAPM (2002) Sebuah utilitas investor (U) ditentukan sepenuhnya oleh rata-rata $\left(\right.$ mean- $\left.\mu_{p}\right)$ dan variance of return $\left(\sigma_{p}^{2}\right)$ dari portofolio investor; yakni, $\mathrm{U}=\mathrm{U}\left(\mu_{p}, \sigma_{p}{ }^{2}\right)$. Di dalam kerangka semacam itu, risiko dari sebuah saham $i$ yang diambil secara individual akan dihitung dengan standar deviasi return dari saham yang diberikan dalam rumus

$\sigma_{i}=\sqrt{\frac{\sum(R i-\mu)}{\sum t}}$ 
Menurut Jurnal Systematic Risk In Emerging Markets: The D-CAPM (2002) Dimana $\mathrm{R}$ dan $\mu$ mewakili return dan rata-rata return. Ketika saham $i$ hanyalah satu dari sekian banyak portofolio yang terdiversifikasi, maka risikonya akan dihitung dengan kovariannya terhadap portofolio pasar $\left(\sigma_{\mathrm{iM}}\right)$ yang ditulis sebagai

$$
\sigma_{i M}=\sum\left[\left(R_{i}-\mu_{i}\right)\left(R_{M}-\mu_{M}\right)\right]
$$

Menurut Jurnal Systematic Risk In Emerging Markets: The D-CAPM (2002) Karena kovarian termasuk tidak terbatas dan tergantung pada skala, maka penafsirannya tidak bisa dilakukan secara langsung. Penghitungan risiko dapat diperoleh dengan membagi kovarian dengan standar deviasi return dari saham $i$, dan standar deviasi return dari pasar, sehingga diperoleh korelasi saham $i$ dengan pasar yang dituliskan sebagai

$\rho_{\mathrm{iM}}=\frac{\sigma_{i M}}{\sigma_{i} \cdot \sigma_{M}}$

Menurut Jurnal Systematic Risk In Emerging Markets: The D-CAPM (2002) Kovarian antara saham $i$ dan portofolio pasar dapat dibagi dengan varian dari portofolio pasar, sehingga memperoleh beta saham $i\left(\beta_{\mathrm{i}}\right)$, yang dituliskan sebagai

$$
\beta_{i}=\frac{\sigma_{i M}}{\sigma^{2}{ }_{M}}=\frac{\sum\left[\left(R_{i}-\mu_{i}\right)\left(R_{M}-\mu_{M}\right)\right]}{\sum\left[\left(R_{M}-\mu_{M}\right)^{2}\right]}
$$

Menurut Jurnal Systematic Risk In Emerging Markets: The D-CAPM (2002) Beta ini juga dapat dituliskan sebagai $\beta_{\mathrm{i}}$ $=\left(\sigma_{i} / \sigma_{\mathrm{M}}\right) \rho_{\mathrm{iM}}$, dan merupakan jenis penghitungan yang paling umum digunakan untuk penghitungan risiko. Penghitungan ini juga satu-satunya tingkatan spesifik perusahaan di dalam model yang sering digunakan untuk memperkirakan return yang diharapkan, CAPM yang ditulis sebagai

$\mathbf{E}\left(\mathbf{R}_{\mathrm{i}}\right)=\mathbf{R}_{f}+M R P \cdot \beta_{\mathrm{i}}$

dimana $\mathrm{E}\left(\mathrm{R}_{i}\right)$ dan $\mathrm{R}_{f}$ melambangkan return yang diharapkan (required return) dalam saham $i$ dan tingkatan bebas risiko, dan $M R P$ melambangkan premi resiko pasar, yang didefinisikan sebagai $\mathrm{MRP}=\mathrm{E}\left(\mathrm{R}_{\mathrm{M}}\right)-\mathrm{R}_{f}, \quad$ dimana $\mathrm{E}\left(\mathrm{R}_{\mathrm{M}}\right)$ melambangkan return yang diharapkan di dalam pasar.

Adapun kriterianya adalah Jika $\mathrm{E}(\mathrm{Ri})<\mathrm{Ri}$ maka sekuritas mengalami overvalued dan keputusan investasi yang bisa diambil para investor adalah melakukan jual/dinvestasi. Jika $\mathrm{E}(\mathrm{Ri})>$ Ri maka sekuritas mengalami undervalued dan keputusan investasi yang bisa diambil para investor adalah melakukan beli/investasi.

Jika tingkat pengembalian yang diharapkan dari saham $\mathrm{E}(\mathrm{Ri})=\mathrm{Ri}$ (tingkat pengembalian saham individu) maka sekuritas mengalami fairvalued (dinilai dalam keadaan seimbang) dan keputusan investasi yang bisa diambil para investor adalah tidak melakukan transaksi beli dan jual. Karena saham tersebut dalam keadaan keseimbangan, sehingga tidak ada keuntungan yang diperoleh dari transaksi pembelian dan penjualan saham tersebut.

Uji statistik yang digunakan ada dua yaitu uji t (parsial) dan uji F. Setiap pengujian pendekatan yang digunakan untuk pengujian hipotesis secara statistik adalah pendekatan signifikan untuk mengetahui benar tidaknya hipotesis nol. Uji hipotesis ini untuk mengetahui apakah tingkat keuntungan berpengaruh positif atau negatif terhadap tingkat risiko. Untuk Variable bebasnya (X) yang diregresi secara bertahap adalah harga saham, IHSG, tingkat suku bunga SBI sedangkan untuk Variable terikat (Y) adalah Ri, Rm, Rf, beta, Eri. 
Uji hipotesis dua arah memiliki dua daerah penolakan Ho yaitu daerah positif (disebelah kanan $\mu$ ). Jika letak nilai $\mathrm{t}$ satat berada disebelah kiri daerah $\mathrm{t}$ kritis negatif atau disebelah kanan daerah positif maka Ho ditolak (signifikan). Namun apabila t stat berada di dalam daerah t kritis (negatif-positif), maka Ho diterima (tidak signifikan).

Hipotesis yang disusun adalah sebagai berikut:

Ho $; \beta=0$, berarti tidak ada pengaruh secara parsial antara variabel bebas terhadap variabel terikat.

Hi $; \beta \neq 0$, berarti ada pengaruh secara parsial antara variabel bebas terhadap variabel terikat.

Uji dua arah wilayah nilai t kritis ada dua yaitu negatif dan positif, sehingga agar mudah dalam memahami ketentuan berikut, nilai t hitung akan dilihat nilai mutlaknya (positif) dengan tingkat probalititasnya 0,05 atau $5 \%$. 1)Apabila $\mathrm{t}$ hitung $>\mathrm{t}$ tabel, maka Ho ditolak dan Hi diterima, berarti pengaruh variabel bebas (Xi) secara parsial terhadap variabel terikat (Yi) adalah signifikan. 2) Apabila t hitung < t tabel, maka Ho diterima dan Hi ditolak, berarti pengaruh variabel bebas (Xi) secara parsial terhadap variabel terikat (Yi) adalah tidak signifikan. Untuk t hitung rumusnya sebagai berikut:

$$
t=\frac{b j}{s . e(b j)}
$$

Notasi :

$\mathrm{bj}=$ koefisien regresi variabel bebas ke-i

S.e $=$ standar error variabel bebas ke-i.

\section{PEMBAHASAN}

Seperti yang dijelaskan sebelumnya bahwa fungsi beta sebagai pengukur risiko sistematik dari suatu sekuritas atau portofolio relatif terhadap risiko pasar. Risiko ini menggambarkan faktor ekonomi secara keseluruhan yang mempengaruhi semua sekuritas yang ada. Risiko sistematis disebut juga dengan beta. Beta adalah besarnya pengaruh perubahan harga suatu saham terhadap perubahan harga saham portofolio pasar Dimana beta dihitung dengan regresi antara return per saham dengan return market.

Tabel 1. Nilai beta

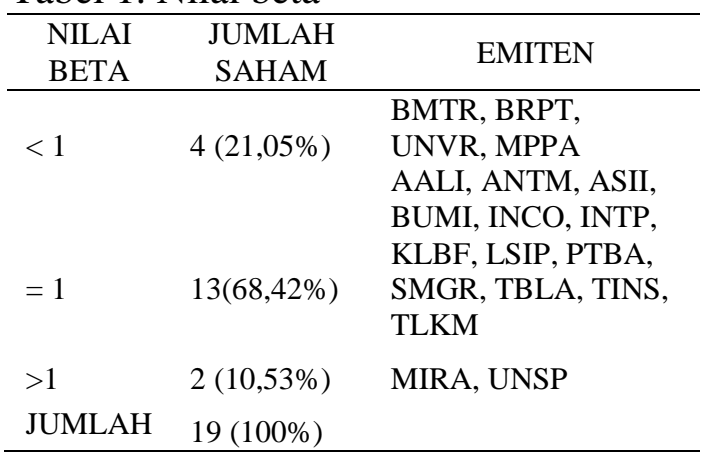

Dari tabel Nilai beta . Nilai beta diatas diklasifikasikan menjadi 3 yaitu $<1,=1,>1$. Dari pembulatan angka nilai beta kurang dari $1 \quad(<1)$ diperoleh perusahaan BMTR, BRPT, MPPA dan UNVR sebesar 0.446705, 0.454898, 0.188726 , dan 0.264748 yang artinya gejolak harga saham lebih lemah atau lebih rendah dari pada gejolak indeks pasar dan memiliki volatilitas lebih rendah sehingga dapat dipertimbangkan risiko lebih rendah dengan potensi return yang lebih rendah atau kurang sensitif terhadap pengaruh pasar atau pengaruh kondisi ekonomi. Untuk beta sama dengan $1(=1)$ diperoleh 13 perusahaan atau $68,42 \%$ dari 19 perusahaan yang dijadikan sampel yang artinya terdapat gejolak harga saham dari 13 perusahaan tersebut sama dengan gejolak indeks pasar. Dan beta yang lebih dari 1 diperoleh perusahaan MIRA dan UNSP yang artinya gejolak harga saham untuk BRPT dan UNSP lebih besar daripada gejolak pasar. 
Tabel 2. Hasil Regresi

\begin{tabular}{|c|c|c|c|}
\hline \multicolumn{4}{|c|}{ Dependent Variable: ERI } \\
\hline \multicolumn{4}{|c|}{ Method: Least Squares } \\
\hline \multicolumn{4}{|c|}{ Date: 07/23/09 Time: 06:39 } \\
\hline \multicolumn{4}{|l|}{ Sample: 119} \\
\hline \multicolumn{4}{|c|}{ Included observations: 19} \\
\hline Variable & Coeff & Std. Error & Prob. \\
\hline BETA & 0.017411 & 0.005796 & 0.0076 \\
\hline R-squared & 0.247682 & Mean dependent var & 0.01168 \\
\hline Adjusted R-squared & 0.247682 & S.D. dependent var & 0.0333 \\
\hline S.E. of regression & 0.028958 & Akaike info criterion & -4.1947 \\
\hline Sum squared resid & 0.015094 & Schwarz criterion & -4.1450 \\
\hline Log likelihood & 40.85031 & Durbin-Watson stat & 1.74688 \\
\hline
\end{tabular}

Beta portofolio yang didapat dari selisih antara Rm-Rf yang disebut sebagai premi risiko sebesar 0,017411 yang bernilai positif kurang dari 1 . Beta portofolio positif diartikan searah dengan gejolak pasar sedangkan beta kurang dari satu artinya gejolak harga saham lebih lemah atau lebih rendah dari gejolak indeks pasar untuk JII dan memiliki volatilitas lebih rendah sehingga dapat dipertimbangkan risiko lebih rendah dengan potensi return yang lebih rendah atau kurang sensitif terhadap pengaruh pasar atau pengaruh kondisi ekonomi.

Menurut Jogiyanto (2000:333) Dalam hubungan jangka panjang Rm-Rf harus bernilai positif atau return dari portofolio pasar lebih besar dari tingkat return bebas risiko. Alasanya karena portofolio pasar lebih berisiko dengan aktiva tidak berisiko, sehingga harus dikompensasi dengan return yang lebih besar dari return aktiva bebas risiko. Dan kesimpulannya adalah pasar memutuskan pembelian saham apabila diatas tingkat bungan ebas risiko atau diatas $1,7 \%$.

Dari hasil regresi diatas terlihat bahwa tingkat probabilitas $5 \%$ atau tingkat signifikansi $95 \%, \quad \mathrm{df}=17$, diperoleh $\mathrm{t}$ tabel sebesar 1,7396 sedangkan untuk $t$ hitung sebesar 3,003693 yang artinya 3,003693>
1,7459 (t hitung > t tabel) maka Ho ditolak dan Hi diterima, berarti pengaruh variabel terikat $(\mathrm{E}(\mathrm{Ri})$ secara parsial terhadap variabel bebas (beta atau yang didapat dari Rm-Rf) adalah signifikan.

Dari hasil regresi didapat persamaan untuk menentukan return yang diharapkan $\mathrm{E}(\mathrm{Ri})$ adalah sbb:

$$
E(R i)=R f+0.017411 . \beta i
$$

Tabel 3. Perhitungan E(Ri) dengan Model CAPM

\begin{tabular}{|c|c|c|c|c|c|}
\hline KODE & $\mathrm{Rf}$ & $\mathrm{Rm}-\mathrm{Rf}$ & $\beta \mathrm{i}$ & $\mathrm{E}(\mathrm{Ri})$ & $\begin{array}{l}\text { Dalam } \\
\text { persen }\end{array}$ \\
\hline AALI & 0.008210 & 0.017411 & 1.402381 & 0.035930 & $4 \%$ \\
\hline ANTM & 0.008210 & 0.017411 & 1.228394 & 0.031473 & $3 \%$ \\
\hline ASII & 0.008210 & 0.017411 & 1.184759 & 0.030355 & $3 \%$ \\
\hline BMTR & 0.008210 & 0.017411 & 0.446705 & 0.011445 & $1 \%$ \\
\hline BRPT & 0.008210 & 0.017411 & 0.454898 & 0.011655 & $1 \%$ \\
\hline BUMI & 0.008210 & 0.017411 & 1.215051 & 0.031131 & $3 \%$ \\
\hline INCO & 0.008210 & 0.017411 & 1.476276 & 0.037824 & $4 \%$ \\
\hline INTP & 0.008210 & 0.017411 & 0.938646 & 0.024049 & $2 \%$ \\
\hline KLBF & 0.008210 & 0.017411 & 0.736093 & 0.018859 & $2 \%$ \\
\hline LSIP & 0.008210 & 0.017411 & 1.311143 & 0.033593 & $3 \%$ \\
\hline MIRA & 0.008210 & 0.017411 & 1.923635 & 0.049285 & $5 \%$ \\
\hline MPPA & 0.008210 & 0.017411 & 0.188726 & 0.004835 & $0 \%$ \\
\hline PTBA & 0.008210 & 0.017411 & 1.287630 & 0.032990 & $3 \%$ \\
\hline SMGR & 0.008210 & 0.017411 & 0.727052 & 0.018628 & $2 \%$ \\
\hline TBLA & 0.008210 & 0.017411 & 1.496484 & 0.038341 & $4 \%$ \\
\hline TINS & 0.008210 & 0.017411 & 1.389191 & 0.035592 & $4 \%$ \\
\hline TLKM & 0.008210 & 0.017411 & 0.667486 & 0.017102 & $2 \%$ \\
\hline UNSP & 0.008210 & 0.017411 & 1.610186 & 0.041255 & $4 \%$ \\
\hline UNVR & 0.008210 & 0.017411 & 0.264748 & 0.006783 & $1 \%$ \\
\hline
\end{tabular}

Dari tabel diatas dapat dilihat perolehan ekspektasi return dengan mengunakan metode CAPM cenderung stabil dan efektif karena dari kesembilan belas perusahaan tidak ada yang mendapatkan return negatif atau mengalami penurunan keuntungan. Return ekspektasi yang positif menujukan prediksi perusahaan tersebut terjadi peningkatan keuntungan contohnya perusahaan BRPT terjadi 
peningkatan keuntungan sebesar $1 \%$ atau sebesar 0.011445 dan perusahaan MPPA diprediksikan tidak mengalami penurunan dan peningkatan keuntungan. Hasil perhitungan return yang diharapkan sebelum dan sesudah mengunakan model CAPM terdapat perbedaan, dapat dilihat pada gambar 1 .

Pada tabel 4. bisa dilihat kriterianya yaitu undervalued, overvalued dan fairvalued. Apabila kriteria saham tersebut undervalued sebaiknya untuk para investor segera untuk dibeli karena dikatakan saham tersebut murah sedangkan apabila saham tersebut overvalued dianjurkan untuk para investor untuk menjual saham

Tabel 4. Saham Undervalued, Overvalued dan Fairvalued (jatuh tempo Desember 2008)

\begin{tabular}{|c|c|c|c|c|}
\hline \multirow{2}{*}{$\begin{array}{c}\text { KODE } \\
\text { PERUSAHAAN }\end{array}$} & & REKUENSI EVEN & & \multirow{2}{*}{$\begin{array}{c}\text { SARAN } \\
\text { KEPUTUSAN }\end{array}$} \\
\hline & overvalued & undervalued & fairvalued & \\
\hline AALI & $19(54,29 \%)$ & $16(45,71 \%)$ & - & Dijual(mahal) \\
\hline ANTM & $15(42,86 \%)$ & $20(57,14 \%)$ & - & \multirow{2}{*}{$\begin{array}{l}\text { Dibeli(murah) } \\
\text { Dibeli(murah) }\end{array}$} \\
\hline ASII & $16(45,71 \%)$ & $19(54,29 \%)$ & - & \\
\hline BMTR & $12(34,29 \%)$ & $23(65,71 \%)$ & - & \multirow{2}{*}{$\begin{array}{l}\text { Dibeli(murah) } \\
\text { Dibeli(murah) }\end{array}$} \\
\hline BRPT & $12(34,29 \%)$ & $23(65,71 \%)$ & - & \\
\hline BUMI & $19(54,29 \%)$ & $16(45,71 \%)$ & - & \multirow{2}{*}{$\begin{array}{l}\text { Dijual(mahal) } \\
\text { Dijual(mahal) }\end{array}$} \\
\hline INCO & $19(54,29 \%)$ & $16(45,71 \%)$ & - & \\
\hline INTP & $18(51,43 \%)$ & $17(48,57 \%)$ & - & Dijual(mahal) \\
\hline KLBF & $9(25,71)$ & $26(74,29 \%)$ & - & Dibeli(murah) \\
\hline LSIP & $16(45,71 \%)$ & $19(54,29 \%)$ & - & \multirow{2}{*}{$\begin{array}{l}\text { Dibeli(murah) } \\
\text { Dibeli(murah) }\end{array}$} \\
\hline MIRA & $12(34,29 \%)$ & $23(65,71 \%)$ & - & \\
\hline MPPA & $14(40 \%)$ & $21(60 \%)$ & - & \multirow{2}{*}{$\begin{array}{l}\text { Dibeli(murah) } \\
\text { Dibeli(murah) }\end{array}$} \\
\hline PTBA & $17(48,57 \%)$ & $18(51,43 \%)$ & - & \\
\hline SMGR & $19(54,29 \%)$ & $16(45,71 \%)$ & - & Dijual(mahal) \\
\hline TBLA & $15(42,86 \%)$ & $20(57,14 \%)$ & - & Dibeli(murah) \\
\hline TINS & $18(51,43 \%)$ & $17(48,57 \%)$ & - & \multirow{2}{*}{$\begin{array}{l}\text { Dijual(mahal) } \\
\text { Dibeli(murah) }\end{array}$} \\
\hline TLKM & $16(45,71 \%)$ & $19(54,29 \%)$ & - & \\
\hline UNSP & $16(45,71 \%)$ & $19(54,29 \%)$ & - & Dibeli(murah) \\
\hline UNVR & $18(51,43 \%)$ & $17(48,57 \%)$ & - & Dijual(mahal) \\
\hline
\end{tabular}

tersebut karena saham tersebut dikatakan mahal dan posisi bagus untuk dijual.

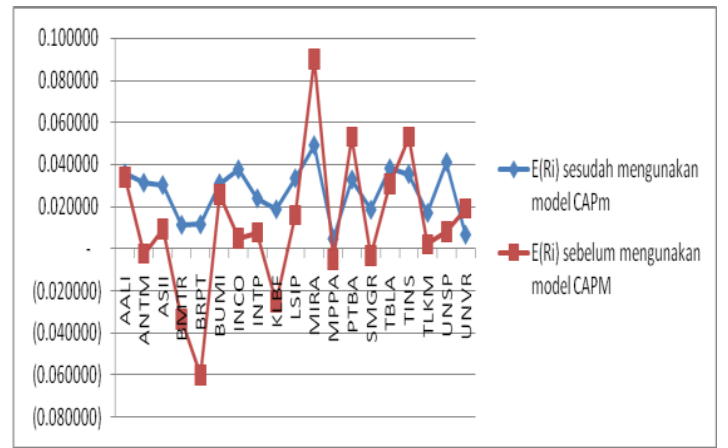

Gambar 1. Pergerakan Tingkat

Keuntungan Yang diharapkan 
Tabel 5. Saham Undervalued, Overvalued dan Fairvalued (Estimasi jatuh tempo Agustus 2009)

\begin{tabular}{|c|c|c|c|c|}
\hline \multirow{2}{*}{$\begin{array}{c}\text { KODE } \\
\text { PERUSAHAAN }\end{array}$} & \multicolumn{3}{|c|}{ FREKUENSI EVEN } & \multirow{2}{*}{$\begin{array}{c}\text { SARAN } \\
\text { KEPUTUSAN }\end{array}$} \\
\hline & Overvalued & undervalued & fairvalued & \\
\hline AALI & $4(57,14 \%)$ & $3(42,86 \%)$ & - & dijual \\
\hline ANTM & $6(85,71 \%)$ & $1(14,29 \%)$ & - & dijual \\
\hline ASII & $1(14,29 \%)$ & $6(85,71 \%)$ & - & dibeli \\
\hline BMTR & $3(42,86 \%)$ & $4(57,14 \%)$ & - & dibeli \\
\hline BRPT & $6(85,71 \%)$ & $1(14,29 \%)$ & - & dijual \\
\hline BUMI & $7(100 \%)$ & - & - & dijual \\
\hline INCO & $5(71,43 \%)$ & $2(28,57 \%)$ & - & dijual \\
\hline INTP & $2(28,57 \%)$ & $5(71,43 \%)$ & - & dibeli \\
\hline KLBF & $3(42,86 \%)$ & $4(57,14 \%)$ & - & dibeli \\
\hline LSIP & $4(57,14 \%)$ & $3(42,86 \%)$ & - & dijual \\
\hline MIRA & $5(71,43 \%)$ & $2(28,57 \%)$ & - & dijual \\
\hline MPPA & $1(14,29 \%)$ & $6(85,71 \%)$ & - & dibeli \\
\hline PTBA & $4(57,14 \%)$ & $3(42,86 \%)$ & - & dijual \\
\hline SMGR & $2(28,57 \%)$ & $5(71,43 \%)$ & - & dibeli \\
\hline TBLA & $7(100 \%)$ & - & - & dijual \\
\hline TINS & $4(57,14 \%)$ & $3(42,86 \%)$ & - & dijual \\
\hline TLKM & $5(71,43 \%)$ & $2(28,57 \%)$ & - & dijual \\
\hline UNSP & $4(57,14 \%)$ & $3(42,86 \%)$ & - & dijual \\
\hline UNVR & $4(57,14 \%)$ & $3(42,86 \%)$ & - & dijual \\
\hline
\end{tabular}

Saran keputusan (Tabel 5) dapat dibandingkan dengan saran keputusan untuk periode 2009 yang jatuh tempo Agustus 2009, dimana pada tabel didapat hasil saham yang undervalued, overvalued dan fairvalued yang jatuh tempo Agustus 2009 yang diolah dari harga saham dari Januari - Juli 2009 kemudian dicari return per saham per periode dan return pasar. Untuk $\mathrm{Ri}, \mathrm{Rm}$ bulan Agutus 2009 dilakukan tren yaitu untuk mengestimasi kejadian yang akan datang atau memprediksi hasil periode selanjutnya. Khusus untuk $\mathrm{Rf}$ di tren mulai bulan Juni, Juli dan Agustus. Saran keputusan yang jatuh tempo pada Desember 2008 dan jatuh tempo Agustus 2009 untuk menganalisa tepat atau tidaknya untuk melakukan jual dan beli saham mengingat pergerakan return berubah dan tidak menentu kadang menyesuaikan kondisi makro.
Investor dapat memperkirakan dari hasil tabel 6. apakah akan tetap dijual sahamnya atau akan tetap dibeli sahamnya karena untuk tiap bulannya harga saham selalu terjadi perubahan mengingat pengaruh krisis global sudah mulai membaik maka diharapkan pergerakan harga saham juga terus meningkat. Pada tabel 6. dibandingkan hasil prediksi jatuh tempo desember 2008 dengan prediksi jatuh tempo Agustus 2009.

Untuk saham AALI, BUMI, INCO, TINS dan UNVR untuk sampai bulan Agustus saham tersebut masih dalam posisi mahal baik untuk dijual. Dan untuk saham ASII, BMTR, KLBF dan MPPA untuk sampai bulan Agustus 2009 saham tersebut dalam keadaan murah dan bisa dibeli untuk menambah aset. 
Tabel 6. Prediksi Perbandingan Saran Keputusan Jatuh Tempo Desember 2008 dengan Agustus 2009

\begin{tabular}{ccc}
\hline KODE PERUSAHAAN & $\begin{array}{c}\text { SARAN KEPUTUSAN JATUH } \\
\text { TEMPO DESEMBER 2008 }\end{array}$ & $\begin{array}{c}\text { SARAN KEPUTUSAN JATUH } \\
\text { TEMPO AGUSTUS 2009 }\end{array}$ \\
\hline AALI & Dijual(mahal) & dijual (mahal) \\
ANTM & Dibeli(murah) & dijual (mahal) \\
ASII & Dibeli(murah) & Dibeli(murah) \\
BMTR & Dibeli(murah) & Dibeli(murah) \\
BRPT & Dibeli(murah) & dijual (mahal) \\
BUMI & Dijual(mahal) & dijual (mahal) \\
INCO & Dijual(mahal) & dijual (mahal) \\
INTP & Dijual(mahal) & Dibeli(murah) \\
KLBF & Dibeli(murah) & Dibeli(murah) \\
LSIP & Dibeli(murah) & dijual (mahal) \\
MIRA & Dibeli(murah) & dijual (mahal) \\
MPPA & Dibeli(murah) & Dibeli(murah) \\
PTBA & Dibeli(murah) & dijual (mahal) \\
SMGR & Dijual(mahal) & Dibeli(murah) \\
TBLA & Dibeli(murah) & dijual (mahal) \\
TINS & Dijual(mahal) & dijual (mahal) \\
TLKM & Dibeli(murah) & dijual (mahal) \\
UNSP & Dibeli(murah) & dijual (mahal) \\
UNVR & Dijual(mahal) & dijual (mahal) \\
\hline
\end{tabular}

Sedangkan untuk saham ANTM, BRPT, LSIP, MIRA, PTBA,TBLA, TLKM, UNSP yang pada saat jatuh tempo Desember 2008 prediksinya saham tersebut dalam keadaan murah dan bisa dibeli dan untuk jatuh tempo Agustus 2009 saham tersebut dalam keadaan mahal dan bisa dijual dan kesimpulannya apabila seorang investor membeli saham pada jatuh tempo Desember 2008 sudah bisa dijual pada Agustus 2009 dan diprediksikan investor akan mendapat keuntungan dari menjual saham tersebut. Dan untuk hasil jatuh tempo Desember 2008 saham tersebut dijual bisa dibeli kembali pada Agustus 2009 yaitu saham INTP dan SMGR.

\section{PENUTUP}

Dari hasil regresi didapat beta persaham adalah rata-rata sama dengan satu $(=1)$ dimana beta bernilai 1 menunjukan bahwa risikon sistematik suatu sekuritas atau porofolio sama dengan risiko suatu sekuritas sama dengan risiko pasar. Beta sama dengan 1 menunjukan gejolak harga saham sama dengan gejolak indeks pasar.

Dari hasil regresi model CAPM didapat beta sebagai premi risiko yang menunjukan nilai positif kurang dari $1(<$ 1) dan dalam hubungan jangka panjang Rm-Rf harus bernilai positif atau return dari portofolio pasar lebih besar dari tingkat return bebas risiko. Alasanya karena portofolio pasar lebih berisiko dengan aktiva tidak berisiko, sehingga harus dikompensasi dengan return yang 
lebih besar dari return aktiva bebas risiko. Dan mempunyai pengaruh yang positif untuk variabel terikatnya adalah (E(Ri)) terhadap beta pasar koefisien $\mathrm{Rm}$-Rf sebagai variabel bebasnya (signifikan untuk uji t).

Model CAPM dapat dijadikan salah satu tehnik memilih saham dan menentukan saham mana yang undervalued, overvalued dan fairvalued, serta dapat dijadikan salah satu metode dalam pengambilan keputusan dalam melakukan investasi di Pasar Modal khususnya pada saham JII di Bursa Efek Indonesia oleh investor. Dalam perhitungan model CAPM didapat return yang positif.

\section{DAFTAR PUSTAKA}

Estrada, Javier. 2002. Jurnal Systematic Risk In Emerging Markets: The DCAPM. Barcelona, Spain : IESE Business School.

Fabozzi, F.J. 1999. Manajemen Investasi. Jakarta : Salemba Empat.

Fanandri, Moch. 2003. Analisis Tingkat Risiko dan Keuntungan Saham Dalam Pembentukan , Portofolio Yang Efisien. Skripsi Tidak Diterbitkan. Malang : Jurusan IESP Universitas Muhammadiyah Malang.

Halim, Abdul. 2003. Analisis Investasi. Jakarta : Salemba Empat.

Husnan, Suad. 1987. Teori Portofolio dan Implikasinya bagi Manajemen Keungan. Yogyakarta: BPFE.

Husnan, Suad. Pudjiastutik, Enny. 1993. Dasar-Dasar Teori Portofolio dan Analisis Sekuritas. Yogyakarta :
Akademi Manajemen Perusahaan YKPN.

Husnan, Suad. 1998. Dasar-Dasar Teori Portofolio dan Analisis Sekuritas. Edisi Ketiga. Yogyakarta : Akademi Manajemen Perusahaan YKPN.

Jogiyanto, H. M. 2000. Teori Portofolio dan Analisis Investasi. Edisi Kedua. Yogyakarta : BPFE.

Kuncoro, Mudrajad. 2003. Metode Riset untuk Bisnis dan Ekonomi. Jakarta : Erlangga.

2008. Modul

Panduan Praktikum Manajemen Investasi dengan Metode Eviews 3.0. Malang: Fakultas Ekonomi Universitas Muhammadiyah Malang.

Supranto .1992. Statistik Pasar Modal. Jakarta : PT Rineka Cipta. 